\title{
Application of CBR systems in the process of energy retrofit of single-family detached houses
}

\author{
Arkadiusz Węglarz ${ }^{1, *}$, and Pawet Gilewski ${ }^{1}$ \\ ${ }^{1}$ Warsaw University of Technology, Faculty of Civil Engineering, ul. Lecha Kaczyńskiego 16, 00-637 \\ Warsaw \\ ${ }^{2}$ Warsaw University of Technology, Faculty of Building Services, Hydro and Environmental \\ Engineering, ul. Nowowiejska 20, 00-653 Warsaw
}

\begin{abstract}
In Poland, there are more than 5 million single-family detached houses, and $35 \%$ among them are non-insulated. In the article, we present a concept of application of the case-based reasoning (CBR) systems to support the process of energy retrofit of single-family detached houses. In the proposed CBR system, the energy retrofit process was described using parameters with text and numeric values and also using linguistic variables defined using fuzzy sets. If an investor, designer or contractor encounters a problem in the process of the energy retrofit, he may look for a solution to this problem or similar problems in the CBR system. If he does not find a solution and creates it himself or modifies an existing one, he should put it in the CBR system so that others can benefit from his experience. The proposed CBR system will help in solving the basic Polish (but also Eastern European) problem of energy-saving constructions which is the lack of adequate knowledge of participants in the investment process.
\end{abstract}

\section{Introduction}

Buildings are responsible for $40 \%$ of the global energy consumption and have a longlasting negative impact on the environment due to the greenhouse gases emission. Therefore, scientists around the world work on the solutions to mitigate these negative effects [1-13]. In the case of newly designed buildings, there are many technical and technological solutions leading to high energy efficiency standards of the buildings are they are economically justified [5-7]. However, in the case of existing buildings, the situation is not that prosperous $[1,3]$. The achievement of passive or zero energy building related to energy retrofit requires a lot of knowledge and experience in the field of possible technical solutions and usually consumes much money, while the choice of renovation and installation technologies is often determined by existing construction solutions in the building [4-7]. Therefore, the decision support tools in the process of energy retrofit become of great value.

\footnotetext{
* Corresponding author: aw@ilipw.edu.pl
} 


\section{Fundamental problems of energy retrofit of single-family detached houses in Poland}

In the Polish conditions the key problems regarding energy retrofit of single-family detached houses include [3]:

- lack of the informations on the existing financial support systems

- lack of energy efficiency audit and energy retrofit project,

- few contractors ensuring the quality of constructions works

- failure to secure the renovated building,

- unexpected changes in the process of energy retrofit

- incorrect order of the performed actions,

- improper preparation of the base for thermal or humidity insulation,

- failure to prepare old walls for attaching insulation

- insufficient attachment of insulation to the support layer,

- leaving the thermal insulation without weather protection,

- fastening thermal insulation boards without keeping the intersection system,

- improper lintels,

- improper application of glue to thermal insulation boards,

- no reinforcement of insulation zones at the edge of the building,

- lack of thermal insulation connectors or their wrong selection,

- unsecured styrofoam from the sun,

- application of too thin layer of insulation,

- not keeping technological breaks,

- use of improper plaster on mineral wool or foamed polystyrene and the use of poor quality mesh,

- replacement of windows for tight and non-use of mechanical ventilation or window diffusers,

- installation of windows without the use of sealing tapes and lack of adequate expansion joints,

- built-in too large or too small windows or setting the window on contact with the jamb

- incorrect window mounting location, or its assembly without supporting blocks as well as anchors and threshold strips,

- inadequate placement and insulation of the window

- poor selection of the heat source and errors in the installation of the heating system,

- lack of proper construction supervision or even a construction manager.

The variety of the presented above problems is extensive, and in some cases, the heating costs of the building are higher after energy retrofit than before it. The concept of CBR (case-based reasoning) was created to support the decision makers in the process of energy retrofit. 


\section{The concept of CBR system}

Case-based reasoning (CBR) is based on comparing a new problem to a problem that already occurred and using a solution that was applicated earlier [14-16]. In the proposed CBR system the process of energy retrofit of single-family detached houses was described using the text and value parameters as well as the linguistic variables defined using fuzzy sets. If an investor, designer, or contractor come across a problem in the process of the energy retrofit, he may look for the solution to this problem or a similar one in the CBR system. If he does not find a solution and creates it himself or modifies an existing one, he should put it in the CBR system so that others can benefit from his experience.

Linguistic variables are represented by four data points (x, T(x), U, MN ), where:

- $\mathrm{x}$ - linguistic variable, e.g., "Size of a single bedroom",

- $\mathrm{T}(\mathrm{x})$ - set of linguistic values of the $\mathrm{x}$ variable (descriptive), e.g $\mathrm{T}(\mathrm{x})=$ (small, large, huge, etc.),

- $\mathrm{U}$ - the numerical domain of the variable (range of values), e.g., $\mathrm{U}=[40 ; 1000] \mathrm{m}^{2}$ usable floor area,

- $\mathrm{MN}$ - the rule of assigning the linguistic variable to fuzzy sets.

The method for assignment of a linguistic variable to fuzzy sets was chosen by describing the values of the linguistic variable, e.g., "small (single bedroom)" with trapezoidal fuzzy numbers, e.g. $A=\left(a_{1}, a_{2}, a_{3}, a_{4}\right)$. The $a_{1}$ value is equal to the smallest usable floor area provided by the respondents for a small (single bedroom). The value of the $<\mathrm{a} 2, \mathrm{a} 3>$ is a range of the area provided by all of the respondents. The $\mathrm{a}_{4}$ value is equal to the highest usable floor area given by all respondents. The method of describing the "small (single bedroom) linguistic value using a trapezoidal fuzzy number is shown on Figure 1.

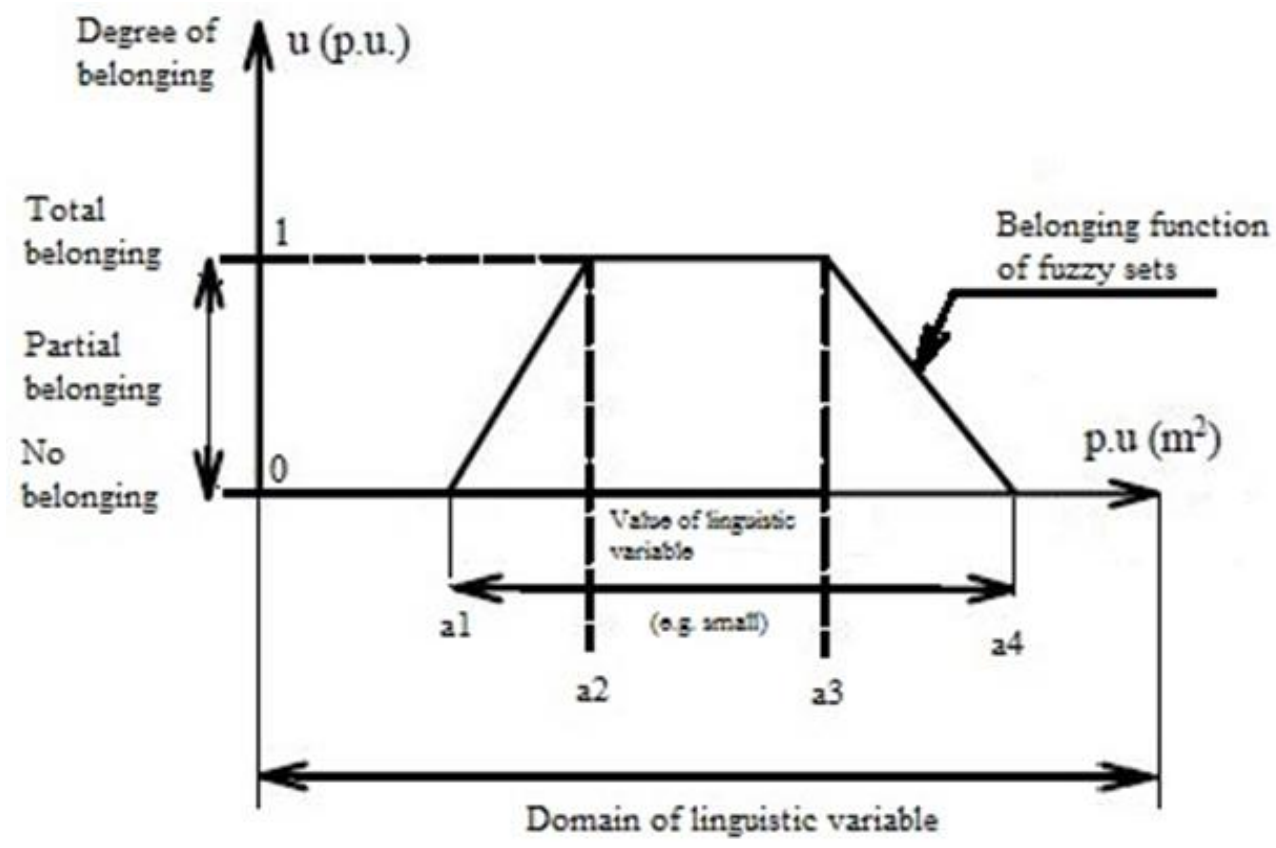

Fig. 1. Creation of trapezoidal fuzzy numbers describing the value of linguistic variables (p.u. usable area) [own elaboration] 
Figure 2 shows an example of the value for the "medium" linguistic variable: "Size of a single-family detached house" described using trapezoidal fuzzy number $\mathrm{A}=$ $(140,160,200,250)$.

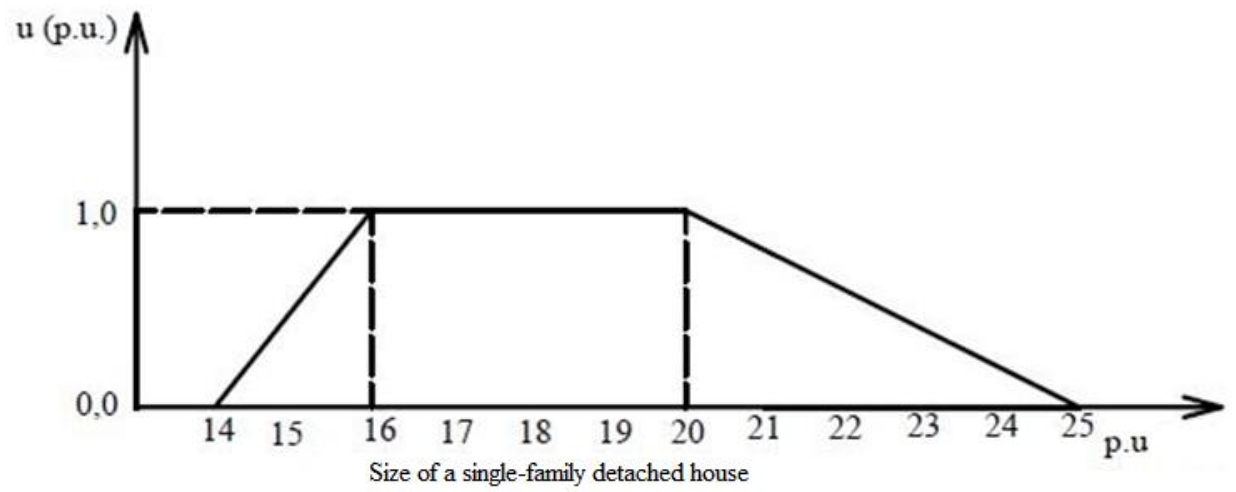

Fig. 2. Creation of trapezoidal fuzzy numbers describing the value of linguistic variables (p.u. - a usable area in tens of meters) [own elaboration]

The proposed CBR system consists of two databases. The first one contains records describing the process of comprehensive energy retrofit of a single-family detached house that has been already completed. The example of such record, based on [1-2], is included in Table 1. The other database contains records describing how to solve a specific problem that occurred during the process of energy retrofit of a single-family detached house. The example of such a record is presented in Table 1.

Table 1. Description of complex energy retrofit done in CBR system

\begin{tabular}{|l|l|l|}
\hline \multicolumn{1}{|c|}{ Parameter } & Type and unit & \multicolumn{1}{c|}{ Characteristic } \\
\hline Usable floor area & Numeric $\left[\mathrm{m}^{2}\right]$ & 92,7 \\
\hline Size of the house & $\begin{array}{l}\text { Linguistic } \\
\text { variable }\end{array}$ & Small \\
\hline $\begin{array}{l}\text { External walls before } \\
\text { modernization }\end{array}$ & $\begin{array}{l}\text { Text variable } \\
\text { thickness and a } 12 \mathrm{~cm} \text { thick brick wall. The value of } \\
\text { heat transfer coefficient U for external walls was } \\
\text { estimated at } 1,014 \mathrm{~W} / \mathrm{m}^{2} \mathrm{~K}\end{array}$ \\
\hline
\end{tabular}




\begin{tabular}{|c|c|c|}
\hline $\begin{array}{l}\text { The floor on the } \\
\text { ground before } \\
\text { modernization }\end{array}$ & Text variable & $\begin{array}{l}\text { The wooden floor was made on wooden joists based } \\
\text { on field stones, formerly the space between the } \\
\text { joists and stones was ventilated, but in recent years } \\
\text { ventilation grids in the foundation walls were } \\
\text { sealed. }\end{array}$ \\
\hline $\begin{array}{l}\text { The ceiling above the } \\
\text { basement before } \\
\text { modernization. }\end{array}$ & Text variable & Bo basement \\
\hline $\begin{array}{l}\text { The roof before } \\
\text { modernization }\end{array}$ & Text variable & Not insulated with a rafter-purlin structure \\
\hline $\begin{array}{l}\text { The windows before } \\
\text { modernization. }\end{array}$ & Text variable & $\begin{array}{l}\text { Box windows of poor technical condition - heat } \\
\text { transfer coefficient estimated at approx. } 3,6 \mathrm{~W} / \mathrm{m}^{2} \mathrm{~K} \text {. }\end{array}$ \\
\hline $\begin{array}{l}\text { Ventilation before } \\
\text { modernization }\end{array}$ & Text variable & Gravitational \\
\hline $\begin{array}{l}\text { How water supply } \\
\text { system before } \\
\text { modernization }\end{array}$ & Text variable & Capacitive electric heater. \\
\hline $\begin{array}{l}\text { Heating system before } \\
\text { modernization }\end{array}$ & Text variable & Heating using tiled stoves \\
\hline $\begin{array}{l}\text { External walls after } \\
\text { modernization }\end{array}$ & Text variable & $\begin{array}{l}\text { The external walls have been insulated with } \\
\text { polystyrene panels, } \lambda=0,031,28 \mathrm{~cm} \text { thick, in the } \\
\text { BSO system. After energy retrofit, the U-value = } \\
0,102 \mathrm{~W} / \mathrm{m}^{2} \mathrm{~K}\end{array}$ \\
\hline $\begin{array}{l}\text { The floor on the } \\
\text { ground after } \\
\text { modernization }\end{array}$ & Text variable & $\begin{array}{l}\text { The existing floor was removed, and a new floor } \\
\text { was made with thermally insulated extruded } \\
\text { polystyrene }(\lambda=0,037) \text { with a thickness of } 18 \mathrm{~cm} \text {. } \\
\text { After energy retrofit, the } \mathrm{U} \text {-value }=0,139 \mathrm{~W} / \mathrm{m}^{2} \mathrm{~K}\end{array}$ \\
\hline $\begin{array}{l}\text { The ceiling above the } \\
\text { basement after } \\
\text { modernization }\end{array}$ & Text variable & There is no basement \\
\hline
\end{tabular}




\begin{tabular}{|c|c|c|}
\hline $\begin{array}{l}\text { Roof after } \\
\text { modernization }\end{array}$ & Text variable & $\begin{array}{l}\text { After the reinforcement of the structure, mineral } \\
\text { wool boards with } \lambda=0,030 \text { and a total thickness of } \\
28 \mathrm{~cm} \text { were laid, and a vapor-tight film was laid. } \\
\text { After energy retrofit, the } U \text {-value }=0,106 \mathrm{~W} / \mathrm{m}^{2} \mathrm{~K}\end{array}$ \\
\hline $\begin{array}{l}\text { Windows after } \\
\text { modernization }\end{array}$ & Text variable & $\begin{array}{l}\text { The windows have been replaced with new } \\
\text { windows of a heat transfer coefficient } U=0,78 \\
\mathrm{~W} / \mathrm{m}^{2} \mathrm{~K}\end{array}$ \\
\hline $\begin{array}{l}\text { Ventilation after } \\
\text { modernization }\end{array}$ & Text variable & $\begin{array}{l}\text { Mechanical with recuperator with a temperature } \\
\text { efficiency of } 86 \%\end{array}$ \\
\hline $\begin{array}{l}\text { Hot water supply } \\
\text { system after } \\
\text { modernization }\end{array}$ & Text variable & $\begin{array}{l}\text { To prepare hot water, heat from the central heating } \\
\text { boiler is used. The heating installation is equipped } \\
\text { with a hot water container }\end{array}$ \\
\hline $\begin{array}{l}\text { Heating system after } \\
\text { modernization }\end{array}$ & Text variable & $\begin{array}{l}\text { A new central heating installation has been made } \\
\text { (with steel panel radiators) in which the source of } \\
\text { heat is a wood gasification boiler }\end{array}$ \\
\hline $\begin{array}{l}\text { Details of the } \\
\text { performed energy } \\
\text { retrofit }\end{array}$ & Text variable & $\begin{array}{l}\text { In addition to the works described in other } \\
\text { parameters, the following actions were made: } \\
\text { Additional insulation of foundation walls, equipped } \\
\text { with PV cells that do not require an external power } \\
\text { supply. Blinds were mounted from the south to } \\
\text { protect the building from overheating. All the doors } \\
\text { in the building have been replaced. }\end{array}$ \\
\hline $\begin{array}{l}\text { Problems that } \\
\text { occurred during the } \\
\text { energy retrofit process }\end{array}$ & Text variable & $\begin{array}{l}\text { It was necessary to reinforce the ceiling by welding } \\
\text { additional IPE } 80 \text { beams along the entire length of } \\
\text { existing steel beams. } 3 \times 40 \text { flat bars were introduced } \\
\text { between the beams, spacing every } 80 \mathrm{~cm} \text {. } \\
\text { The roof truss was in deplorable technical condition } \\
\text { and also required reinforcement. }\end{array}$ \\
\hline $\begin{array}{l}\text { Computed annual } \\
\text { thermal energy } \\
\text { consumption before } \\
\text { energy retrofit }\end{array}$ & $\begin{array}{c}\text { Numeric } \\
{[\mathrm{kWh} / \text { year }]}\end{array}$ & 40932 \\
\hline $\begin{array}{l}\text { Computed annual } \\
\text { thermal energy } \\
\text { consumption after } \\
\text { energy retrofit }\end{array}$ & $\begin{array}{l}\text { Numeric } \\
{[\mathrm{kWh} / \mathrm{rok}]}\end{array}$ & 11289 \\
\hline Energy savings & Percentage & 72 \\
\hline
\end{tabular}




\begin{tabular}{|l|l|l|}
\hline $\begin{array}{l}\text { Standard of the } \\
\text { building after energy } \\
\text { retrofit }\end{array}$ & $\begin{array}{c}\text { Linguistic } \\
\text { variable }\end{array}$ & Low-energy \\
\hline Cost of energy retrofit & Fuzzy number & Around $45000 €$ \\
\hline
\end{tabular}

The example of a record that represents a problem encountered during the energy retrofit process is presented in Table 2.

Table 2. Record in the CBR system describing the problem and its solution that occurred during the energy retrofit process

\begin{tabular}{|c|c|}
\hline $\begin{array}{l}\text { Definition } \\
\text { of the } \\
\text { problem }\end{array}$ & Solution \\
\hline $\begin{array}{l}\text { Installation } \\
\text { of windows } \\
\text { in the } \\
\text { insulation } \\
\text { layer }\end{array}$ & $\begin{array}{l}\text { The best solution is a tight, three-layer assembly, in which the assembly foam } \\
\text { (forming a thermal and acoustic insulation layer) is protected by appropriate } \\
\text { insulation layers: vapor barrier and vapor permeable. These layers (vapor-tight } \\
\text { from the inside, from the outside vapor permeable) prevent the penetration of } \\
\text { moisture and destruction of the foam. However, the method and place of fixing the } \\
\text { window in the wall depend on the type of wall. In the case of monolayer walls (one } \\
\text { load-bearing wall without insulation), the window is mounted in the middle of the } \\
\text { load-bearing wall thickness, using a thermal insulation curtain covering the lintel } \\
\text { and the window edge to improve the energy parameters. In the case of double-layer } \\
\text { walls (load-bearing wall and external thermal insulation), the window is installed } \\
\text { in the thermal insulation plane and not on the edge of the load-bearing wall. To } \\
\text { improve the energy parameters, the lintel and window edge are covered with } \\
\text { insulation in which the window is installed. In the case of three-layer walls (load- } \\
\text { bearing wall, thermal insulation, and curtain wall), the window, similarly as in the } \\
\text { case of a double-layer wall, should be placed in the insulation plate and covered } \\
\text { with both thermal insulation and curtain wall. }\end{array}$ \\
\hline
\end{tabular}

The manner of using the proposed CBR system will depend on the problem that the user wants to solve. For example, if the building owner wants to trace the energy retrofit process of a house of similar size, shape or construction technology, it is necessary to pose the question to the first system database. The database search process is a multi-stage. In the first stage, all projects are searched for which the linguistic value of the linguistic variable "Size of a single-family house" is consistent with the value of this variable specified in the query to the CBR system. For example, we are looking for a "small" house. In subsequent stages, already on a limited number of records describing the energy retrofit process of "small" houses, the compliance of all other parameters expressed by linguistic variables or variables with numerical values is checked. For each project of a "small" house, there are counted cases of compliance of the parameter values in the description of the energy retrofit process and the query to the CBR system. As the solution with the highest degree of similarity [16], the one which is selected represents the highest value of the CBR response counter according to the investor's expectations. 
However, if for example, a designer performing a house energy retrofit construction project would like to learn about the best way of warming a balcony, he asks a question to the second base of the CBR system, using the keywords: balcony insulation. Asking questions by users of both databases will be supported by an expert system.

\section{Summary and conclusions}

In the paper, we presented the application of the concept-based reasoning based for the energy retrofit of single-family detached houses. The performed analysis shows that application of CBR system is very useful in the process of energy retrofit.

While looking for the optimal solution regarding the scope of energy retrofit actions several aspects should be considered in the field of conservation, aesthetic and technical considerations. Also, the investments costs and their impact on subsequent heating charges should be considered. The effective energy retrofit must be done comprehensively, i.e., considering not only the building envelope but also installations and heat supply systems, as well as ventilation systems. One of the most significant problems in the process of energy retrofit is the incorrect order of the actions. E.g., replacement of the boiler and the beginning and then insulation of walls and replacement of windows.

The proposed CBR system helps to avoid many problems that investors face during the process of energy retrofit of the single-family detached house. Moreover, it will help to solve the frequent Polish (and also Eastern European) problem of energy-saving structures which is the lack of adequate knowledge of participants in the energy retrofit investment process.

\section{References}

1. M. Pierzchalski, IGI Global, 248-274 (2018)

2. D. Pierzchalska, A. Węglarz, Mat. Bud., 1, 23-25 (2016)

3. Strategy for modernization of the buildings: road map 2050, Europ. Clim. Found. (2014)

4. S. Firląg, Cz. Te. Bu. 107 (2-B), 49-57 (2010)

5. A., E. Kaliszuk-Wietecka, Sustainable construction. Selected problems in building physics (Wydawnictwo Naukowe PWN, 2017)

6. M. Klimczak, J.Bojarski, P. Ziembicki, P. Kęskiewicz, En. and Buil. 169, 141-147 (2018)

7. M. Piasecki, K. Kostyrko, S. Pykacz, Jour. of Buil. Physics , 3 ss. 294-289 (2017)

8. W. Gilewski, A. Al Sabouni-Zawadzka, Arch. of Civ. and Mech. En., 15, 469-478 (2015)

9. A. Al Sabouni-Zawadzka, Arch. Civ. Eng., 60, 517-534 (2014)

10. A. Al Sabouni-Zawadzka, W. Gilewski, App. Sci., 8, 1-14 (2018)

11. A. Wȩglarz, P.G. Gilewski, Pro. Engin., 153 (2016)

12. A. Wegglarz, P. G. Gilewski, MATEC Web of Con., 117, 1-7 (2017)

13. W.R. Terlikowski, MATEC Web of Con., 117 (2017)

14. S. Zbroja, A. Ligęza, Proc. Int. Conf. Syst. Sci., 2 (2001)

15. A. Kempa, Tech. prze. wie. w SWO, 283-290 (2007)

16. M. Meler-Kapcia, Log., 4, 7244-7251 (2014) 